\title{
Preserving identity while reorganizing urban spaces
}

\author{
Alena Stepanchuk ${ }^{* 10000-0003-3109-6634]}$, Margarita Salyakhova1[0000-0003-3350-6780], and Victoria Salyakhova ${ }^{2}$ \\ ${ }^{1}$ Kazan State University of Architecture and Engineering, 420043 Kazan, Russia \\ ${ }^{2}$ Design Office MORE, 108801 Moscow, Russia
}

\begin{abstract}
The article discusses the issues of preserving the local identity of urban areas, identifying its tangible and intangible components during the reorganization of open public spaces. The concept of festivalization of space, as a way of reflecting the intangible aspects of the history of the territory, as well as adding or changing the scenario of using the urban environment, is disclosed. The classification of temporary architectural structures, which are an integral part of the process of festivalization of public spaces, is proposed. The territory chosen for the study was a park in Kazan which has a rich history and was reorganized. In the study of the territory, general scientific methods, methods of field research, of interdisciplinary synthesis, analysis of participatory design's results, as well as demographic, urban planning analysis were used. The complex of the carried-out studies made it possible to identify the problems and resources of the territory. The results of the study are recommendations for the formation of public urban spaces, taking into account local identity, preserving the function of socio-cultural interaction of residents, organizing scenario use by means of festivalization with the inclusion of temporary architectural structures.
\end{abstract}

Keywords. Local identity of urban areas, festalization of space, scenario of using the urban environment, temporary architectural structures.

\section{Introduction}

\subsection{The relevance of research}

Today, many cities in Russia face a number of difficult tasks related to preserving local identity and improving the comfort of the urban environment. The urban environment is considered by the state as one of the key resources for the strategic development of Russia (Passport of the priority project «Formation of a comfortable urban environment», approved by the Presidium of the Council under the President of the Russian Federation for strategic development and priority projects, minutes of April 18, 2017 No. 5). In 2016, the Ministry of Construction of Russia began the implementation of the federal project «Formation of a Comfortable Urban Environment». It was launched as part of the Housing and Utilities and Urban Environment national project.

\footnotetext{
*Corresponding author: alena.stepanchuk@bk.ru
} 
Discussions of the section «Creative Environment and Urbanism» at the VIII St. Petersburg International Forum, held on November 14-16, 2019, were devoted to regional development strategies based primarily on local identity. Architects who participated in the Forum offered options for revitalizing cultural heritage sites and public spaces, composing different stories based on international experience. Not only tangible aspects of the cultural heritage were considered, but also the successful experience of identifying, revitalizing and actualizing the intangible aspects of culture. Thus, the recipe for Kolomna marshmallow, which was known throughout Russia in the 19th century and was recreated for the Ice House festival in 2008, became the driver of the creation of the Museum of Disappeared Taste. Later it enlarged to the Kolomensky Posad museum and creative cluster based on 14 historical themes about two hundred small and medium-sized companies. In 2016, this project received the Russian Government's Tourism Award, and in 2017 was nominated for the prestigious Best European Museum 2017 (EMYA) award [1]. After 10 years of the project's implementation, the depressive, dying out historical part of the city has turned into an investment-attractive territory.

Much attention is also paid to the issue of improving the comfort of cities at the level of municipalities. The Program for the Development of Public Spaces of the Republic of Tatarstan, which has been implemented since 2015, has become one of 20 projects included in the list of finalists of the Aga Khan International Award for Architecture in 2019. The perception of the whole image of the city and the image of its local public spaces is formed on the basis of the significance and identity of the place [2]. The successful experience of designing public spaces in Tatarstan testifies to the demand for territories that are associated with historical events and are carriers of symbolic value.

Today in Russia there have been significant changes in approaches to the formation of public spaces. When developing projects for their reorganization and renovation, the needs of the population are taken into account; established traditions, tangible and intangible aspects of cultural heritage are identified and preserved; conditions are created for cultural retransmission and the inclusion of intangible cultural heritage in the modern life of society.

The organization of events helps to activate the territory, make it viable and attractive. «There is an opportunity to enhance the image either by retraining the observer or by rebuilding the environment» [3]. With the expansion of the spectrum of socio-cultural diversity, taking into account the cultural and historical context, the level of emotional attachment of people to the territory increases, personal closeness and connection of the individual with the city are formed. Urban identity in the process of functioning of public spaces can be transmitted by means of festivalization - reproducing the history of the city, maintaining the tradition of festivals, various urban mass events and holidays [4]. The architectural and spatial organization of the festival assumes the use of objects of temporary architecture, influencing the formation of functional zoning of the territory, modeling the scenario of the use of space.

In Russian architectural practice, there are many vivid examples of the implementation of projects for the improvement of public spaces. Within the framework of this article, the territory of the park near the Community Centre named after Said-Galeev, located in the city of Kazan (Republic of Tatarstan, Russian Federation), is considered. The territory of the park is interesting, first of all, from the point of view of preserving the originality and identity of the territory. Through the reconstruction of parks, such as the park named after Said-Galeev, the multi-layered social structure of Kazan is being restored. As a result of design solutions, this urban area has acquired a strong driver for further sustainable development based on the interaction of residents and all interested parties. It is worth noting the high level of local selfawareness: the awareness of the residents of the uniqueness of the place, the positive perception of the place, the cohesion of the urban community, the ability to self-organize, the desire to preserve and strengthen the identity of the place. Reproduction of the local identity of the park territory is associated with many events, but, first of all, with certain rituals, e.g., honoring the memory of the fallen soldiers in the Second World War in the area of the memorial complex. 


\subsection{Research goals and tasks}

The goal of this article is to identify and analyze the components of the concept of local identity of public spaces, as well as to determine approaches to its translation during the reorganization and reconstruction of the park near the Community Centre named after SaidGaleev in the village of Derbyshki in the city of Kazan.

The following were identified as the main tasks: the study of interdisciplinary aspects, world trends and approaches to the formation of the concept of «local identity» in the reorganization of public spaces; research of ways to festivalize public spaces with the use of objects of «temporary architecture» in the aspect of the concept of «local identity»; development of recommendations on the use of the methodological arsenal in the reorganization of the public space of the park near the Community Centre named after SaidGaleev with the preservation of the local identity of the territory.

\subsection{Analysis of literature}

Today, there is no doubt about the need for a comprehensive pre-project study of the designed public space, including historical analysis, analysis of the cultural potential of the territory, analysis of the local community (Community), identification of their views and expectations from the territory, determination of the target audience, its expectations and needs, etc. Based on the results complex pre-project analysis forms a complete picture of the local identity of the territory, reveals the internal advantages of its development, identifies problems and determines the main ways of their solution.

Sociologists, geographers, philosophers, culturologists, and architects are engaged in the study of the phenomenon of urban identity, which was introduced into Russian scientific literature by E. Erickson [5]. In recent decades, research has been conducted at the junction of several sciences. They are urban sociology (Urban sociology) which studies the image of the city, its perception by residents and tourists, the symbolic load of the urban environment [6]; perceptual psychology which examines the subjective state of a person in the architectural environment, as well as his ability to remember events related to the territory, build associative connections, interpret the meanings and meanings of forms, and form a «sense of place» $[7,8]$.

N. Diaghileva in the study of sociological aspects of identity, he notes a different understanding of this phenomenon: «urban identity» - «the perceptions of city residents about themselves as residents of this (their) city», «city identity» - ideas about the city, which describe «its essence, specificity, features, similarities and differences with other cities «and» identity with the city» - the perception of a city by a person «as the context of an individual biography» [4]. Within the framework of this article, the authors will focus on the first version of understanding the phenomenon of urban identity, taking into account the unity of the socio-cultural space of the city.

The city has physical boundaries, fixed in space, and symbolic boundaries, formed by the townspeople, taking into account the perception of the city as their own, on the basis of knowledge of the history of their city, satisfaction with the social circle of communication. The symbolic boundaries of the city are based on the image of the city. At the same time, in parallel, there are two types of images of the same city: each resident's «own city» associated with places of personal significance, with subjective experiences and memories, and «our city» is a collective image of the city formed by the urban community $[4,6]$. M. Yakovleva notes that «the townspeople are one of the most general groups to which an individual can belong; and it is the city symbol that should become and, as a rule, is the mechanism through which the urban identity is formed, the connection with the urban community» [6]. By revealing the key points of the collective image of the city, created by superimposing a 
plurality of individual images [9], it possible to form public spaces that enhance the residents' sense of urban identity [10].

The complex process of perception of the urban environment is formed, among other things, under the influence of sounds. The concept of «soundscape» was formulated back in the $1960^{\text {s }}$ by the founder of acoustic ecology R. Murray Schafer. This definition was first formed during the first field studies of the World Soundscape Project (WSP), organized by Shefer together with colleagues at the university. Soundscape is defined by him as «polyphony, the unity of many audible elements» [11] or as sound information perceived by a specific person in a specific place. The terminology he introduced helps to explain the idea that the sound of a particular place can express the individuality of a community, its identity within the space, which can be recognized by its soundscape along with local architecture, established customs and traditions. According to K. Mayorova, «the sound environment of the city forces us to certain patterns of behavior and its comfort is determined, first of all, by the content of the sound. Therefore, its production should be carried out taking into account the interests of others» [12]. The filling of the space can be different: these are the sounds of people when moving (on foot, by bicycles, scooters, etc.), performances of street musicians, etc. A balanced soundscape is formed by filling it with natural sounds (birdsong, water murmur, foliage noise). Exploring the territory from the point of view of this aspect, it is possible to fix the behavioral reactions of a person to a particular sound and to simulate in the future the trajectory of people movement [13].

A disdainful attitude towards the process of identifying, forming and maintaining the symbolic identity of the city may have following consequences: the «facelessness» of the districts, acts of vandalism, an increase in the level of anxiety among the residents of the district, dissatisfaction with the urban environment and irritability, the appearance of «forgotten», «lost» districts in the city, as well as a discrepancy. There is a semantic dissonance between the official and actual meanings and meanings of the territory. Thus, it is extremely important in the process of designing public spaces to take into account the peculiarities of the formation of the city's symbolic identity, to identify and preserve the characteristic features of the uniqueness of the city $[14,15]$. At the same time, the local identity of a certain territory should be considered as one of the facets of the symbolic space of the city as a whole.

Symbolic factors in the formation of local identity include iconic places of the city, local myths and stories, urban symbols [4], which are involved in the process of space festivalization (eventification, festivalization) - event saturation of public space with new scenarios of use: festivals [16], exhibitions, fairs, traditional festivals, master classes, etc. Within the framework of the «experience economy», public spaces are transformed into "theaters" [17]. Festivalization can act as a system-forming element of urban space development. According to R. Janiskee, festivals are official programs that include and enjoy activities, entertainment or events that publicly celebrates an event, phenomenon or aspect of life [18]. Providing space for a festival or a performance enables people to communicate, be direct participants and even authors of projects. At the same time, festivalization contributes to the strengthening of communicative ties and becomes a tool for conveying the identity of the territory, its image and the spirit of the place, and in the future can give an impetus for the development of the adjacent territory of the city [19-21].

The joint creative activity of the participants in the process influences their behavior they become not just users, but active citizens. During active participation, there is a process of actualization of the intangible cultural heritage, its return to the living socio-cultural environment $[22,23]$. At the same time, temporary architectural structures are part of the ongoing socio-cultural processes and contribute to the transformation of the urban environment, creating conditions for a comfortable formation of the environment.

Co-creation trends can be traced not only at the level of the use of urban space by visitors (locals and tourists), but also at the level of territory planning and approaches to its design. 
Today, the concept of participatory design is also called inclusive design [24-26] and includes co-creativity, co-participation in the project process of all interested parties (local residents, administration, property owners, etc.). «Design creativity within such a framework ceases to be a «cabinet» affair. It is transmitted in a situation of dialogue with users, and presupposes empathy, that is, perception from the standpoint of the users themselves» [27]. This approach to design allows architecture and urban space to become more reflective and responsive, and promotes sustainable social innovation [28-30].

So, in 2016 at the World Architecture Festival, the second place in the category of future master plans was awarded to the urban planning project Co-Create Charoenkrung, which was initiated by the Thailand Center for Creativity and Design (TCDC) and developed by the ShmaSoEn studio. The project called for the reorganization of Charoenkrung, one of the oldest districts in Bangkok, into a creative district to house creative industries. The success of the project stems from the application of an inclusive design strategy, close collaboration with TCDC and engagement with the local community to ensure long-term and sustainable development [31]. At all stages of the design, interaction with the public was carried out in the following way: project seminars were organized, focus groups were selected, voting was arranged, working models were created, assessment sessions and public hearings were organized.

To maintain social balance, local projects are used. The residents are directly involved into such projects as: the creation of art projects, the arrangement of venues for performances, exhibitions of contemporary art. Residents become co-authors of events and festival programs. Involvement in the gaming, eventful environment gives the participant the opportunity to experience a different role and even another profession, for example, the role of a designer or an architect.

According to L. Lofland, the main characteristics of public spaces, which are the key to its successful functioning: convenience, pleasant image, variety of use of space and activities, sociality, pleasure from interaction, public loneliness and observation of people, «carnival» (the possibility of playing, festival, getting rid of their true identity, purchasing new masks) [32].

According to A.L. Gelfond, «public space is a space for communication and social activity, organized in accordance with the dominant function» [33]. The environment for Lynch, the theorist and expert of urban planning, acts as something holistic, almost indestructible. «In the modern context of the city development strategy, public space is viewed not just as an additional element of the city, but as a component that changes its appearance, as a «city living room» [34]. Parks, squares and other typologies, competently integrated into the urban structure, create a single social and recreational framework, shaping the image of the city, transforming adjacent territories and having a positive impact on its economy. At the same time, such an interpretation of the urban environment is aimed primarily at improving the environment and reducing the negative impact of the metropolis. In the work of Jane Jacobs [35] «the vitality of an urban ecosystem, as well as a natural one, is ensured by a combination of various components». Their interconnection, primarily visual, is provided in various ways, including with the help of objects of the urban environment, including temporary architectural structures.

At the same time, it should be borne in mind that public space can be used not according to the planned scenario. That is, the expectation of a project to create a completed ideal space does not ensure its future success. At the initial stage, it is necessary to set an impulse for its development as a result of priority changes. Then, get feedback and move on, so that the space works, changes and becomes more lively and in demand. «Perfection is the enemy of implementation», noted Nathan F. Hommel, director of planning and design at the University City District (USA), in his lecture at the 2019 World Urban Parks Congress in Kazan [36].

The use of temporary and easily erected architectural structures during the festivalization of public spaces makes it possible to supplement or change the scenario of the use of space, complement urban ensembles, enhance the significance of an event place, and emphasize its 
local identity. The concept of «temporary architecture» is rather arbitrary. The existence of temporary structures as architectural facilities at a certain place is always limited by time. Depending on the size and duration of the existence of an architectural structure, its concepts are formed as «architectural facility» and «small architectural form» or «design object» (for example, information design objects). And the less the time parameter is, the more mobile the structure itself will be. A classification of temporary architectural structures is proposed according to the following criteria:

1) by the environment-forming factor:

- dominant structure;

- construction-accent;

- landmark building.

2) By style orientation:

- an element of cultural and symbolic space;

- an element modeling the environment;

- an element that enhances the emotional and visual characteristics of the environment.

3) By functional purpose:

- objects as part of public space;

- objects as elements of urban events (festivals, competitions, holidays, exhibitions, etc.).

4) By the degree of temporality:

- one-time use (for the duration of events, festivals);

- multiple use (seasonal, year-round, for a certain period).

5) By the nature of mobility:

- collapsible mobile structures;

- transforming mobile structures.

6) By building materials used:

- as a supporting frame: wood, metal;

- as enclosing structures and coatings: wood, glass, ice, metal sheets, plastic, awning and fabric coverings.

Thus, it is worth highlighting the main trend in the transformation of public spaces:

- focus on the formation of a person's sense of belonging to a place through the understanding of local identity;

- application of participatory design methods;

- festivalization of urban space - eventful saturation of the space with cultural events;

- use of temporary architecture facilities.

\section{Materials and methods}

The study used general scientific methods: theoretical comparative analysis, classification, logical modeling, which made it possible to systematize the material, to identify modern trends in the reorganization of public spaces in terms of identifying and broadcasting the local identity of urban areas, to determine ways of festivalizing public spaces for the socio-cultural actualization of the intangible component of cultural heritage, to reveal the principles of formation of temporary architecture facilities, as components of the process of festivalization.

To assess the current state of the territory of the park zone, the method of field research and photographic recording were used. The method of interdisciplinary synthesis which includes conducting a sociological survey of local residents and experts in the field of urban development, identifying the features of the territory, identifying all urban subjects and stakeholders (stakeholders) and models of their behavior made it possible to involve all stakeholders in the design process and obtain empirical data on priority areas development of the territory. A retrospective analysis aimed at identifying the key stages in the development of 
the park territory consisted in the collection, systematization and generalization of historical data. It revealed the tangible and intangible components of the local identity of the territory.

Demographic analysis made it possible to identify the gender and age composition, population density in the Soviet district of Kazan and the village of Derbyshki, on the territory of which the park named after Said-Galeev is located. Urban planning analysis made it possible to obtain data on the current percentage of various functional zones, area of housing development, the number of cultural, business institutions and social service facilities, data on transport and pedestrian connections both within the territory, and on the connectivity of the park with the rest of the city. As a result of the complex of studies carried out, the resources of the territory and its problems were identified and tasks were set to solve them.

\section{Results and discussion}

\subsection{The historical significance of the territory near the Community Centre named after Said-Galeev}

The territory is located in the Soviet district of Kazan in the settlement of Derbyshki. Sahibgarei Said-Galiev (03/06/1894-10/29/1938) was a Soviet statesman and party leader. The Community Centre named after Said-Galeev was opened in 1959; today it is recognized as a cultural heritage site of local importance. From that time on, the development of the park began. The authors identified the following periods of the park's development:

1. Period 1917-1945 - foundation of the settlement of Derbyshki (1932); formation of the park territory on the basis of the forest; functional areas: dance floor, summer cinema, sports grounds («gorodki» playground, volleyball); landscaping: Scots pine forest; ordinary planting of balsam poplar; hedge of yellow acacia.

2. Period 1946-1956 - construction of the Raketa stadium; new functional area: stage; electrification of the park; the emergence of dirt roads; landscaping: group planting of birch warty bird cherry Maak, viburnum ordinary, the formation of bosquets from ash-leaved maple.

3. Period 1957-1976 - opening of the Community Centre named after Said-Galeev (1959); formation of a regular layout, further improvement; erection of structures and small architectural forms: entrance lobby, stands with information propaganda, monument to fallen heroes, «fountain of tears»; relocation of the main square and alley; asphalting of main roads; landscaping: ordinary planting of prickly spruce, hedge of black hawthorn and rose.

4. Period 1977-1991 - reconstruction of the monument to the fallen soldiers (replacement of the facing), repair and improvement of the adjacent territory; construction of a metal fence; current care of the plantings.

5. Modern period - in close proximity are: the Said-Galeev Community Centre with a reconstructed square and a fountain, a sports complex with a stadium and a swimming pool, a school, a kindergarten, residential buildings. Residents of this area are active users of the territory where events are held in memory of The Second World War (WWII), they go for walks, ski, go jogging.

The functional content of the territory indicates the all-season use of this park. It is noteworthy that some of the inhabitants of the settlement of Derbyshki are those who were taken out of the besieged Leningrad during the Second World War. Therefore, to realize the idea of preserving the memory of the tragic events a monument to the fallen soldiers was erected and an eternal flame and a memorial site were installed at the initiative of the residents in 1964. In the settlement of Derbyshki and the park, festive demonstrations with flags, flowers, music sounded. This period was marked by bright events, collective spirit and solidarity of people. Therefore, the rich history of the settlement of Derbyshki, the diverse eventfulness of the park itself, the fate of bright initiative residents formed the basis for the formation of the concept of reconstruction of the park while preserving local identity with a modern interpretation. 


\subsection{Territory development problems and resources}

The creative group at the Mayor's Office of Kazan (head D. Tolovenkova, chief architect of the project V. Salyakhova, and architectural department of strategic planning MBI «Kazgrazhdanproekt») began work on a project to reorganize the park in 2020 as part of the Program for the Development of Public Spaces of the Republic of Tatarstan. On the basis of the comprehensive analysis carried out, the problems of the territory have been identified that require a number of reconstructive measures. The measures include the creation of an orderly structure of the park that provides a convenient interconnection of all functional zones, an increase in the area of paving of sidewalks and platforms, as well as the solution of the problem of illumination of the territory of the park and the restoration of monuments. The main problem that needs to be addressed is the restoration of «intangible elements» that contribute to the maintenance of the identity and spirit of the place, the restoration of sociocultural ties through the organization of scenario use, that is, the festivalization of the territory with the inclusion of temporary small architectural forms. For the townspeople the park space should become a large space of freedom, an urban living room with the provision of conditions for the realization of their interests.

As the main scenarios for using the park's territory, residents assume a quiet rest in the park forested area and active recreation with children, as well as sports. The lack of the necessary infrastructure in the park for sports, events, recreation and food outlets characterizes the territory as uncomfortable, designed for a short stay. A distinctive feature of the park is a developed green recreational area with centuries-old pines, spruces, birches and maples, which makes it possible to create different types of quiet recreation: family vacations, organized seating areas with modern outdoor furniture, functional lawns, benches.

Based on the above, a rating of key problems has been identified:

- the park does not work as a single space and, due to this, is not fully utilized;

- objects of historical heritage need restoration;

- lack of navigation in the park;

- low level of landscaping;

- lack of infrastructure facilities, including sports;

- it is unsafe to be in the park;

- lack of interest in staying in this territory among the younger generation.

The preserved iconic structures located in the park zone have signs of authenticity that carry confirmed historical information. In order to have more convincing information and to influence people with a great emotional message, it is necessary not only to preserve the monuments, but also to think over an architectural and conceptual solution, including them in the modern socio-cultural space of the city.

\subsection{Territory development concept}

The concept of the park near the Community Centre named after Said-Galeev is based on the rich history of the settlement of Derbyshki and the eventful nature of the park itself, which was a traditional venue for various city events (traditions of festivalizing space). The concept was formed on the idea of reviving the retro atmosphere of the $1960^{\mathrm{s}}$ in the park. The proposed design solution for the decoration of the main boulevard in the retro style is intended to preserve the connection between generations, to ensure the continuity of history, to pass on to the next generations through the atmosphere of the park the main socio-cultural values and elements of intangible cultural heritage (Fig. 1). 


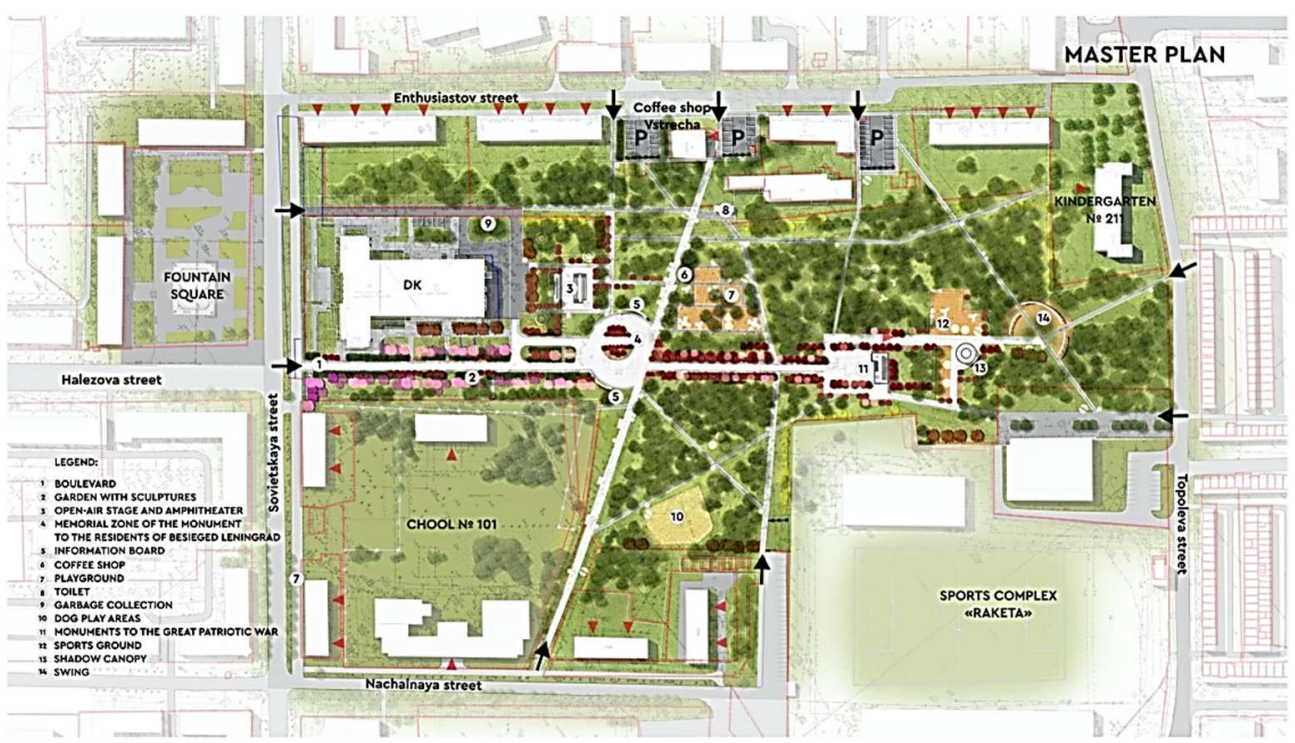

Fig. 1. Scheme of the master plan.

The concept is based on the restoration and recreation of the lost sculptures in the spirit of the Soviet era. The existing improvement elements will be supplemented with new ones in the general style: classic cast-iron benches along the alley with lanterns; vending machines with soda in a retro style, information stands at the park entrances. The local identity of the park is also reflected in the design of cafes, pavilions and small architectural forms. The use of ornaments and patterns typical of $1960^{\mathrm{s}}$ wooden park architecture has been suggested.

Based on the results of the collaborative design, the functional zones of the park, their content and location were determined. Structurally, all the main zones are located on the main front alley of the park, as the main compositional axis (Fig. 2).

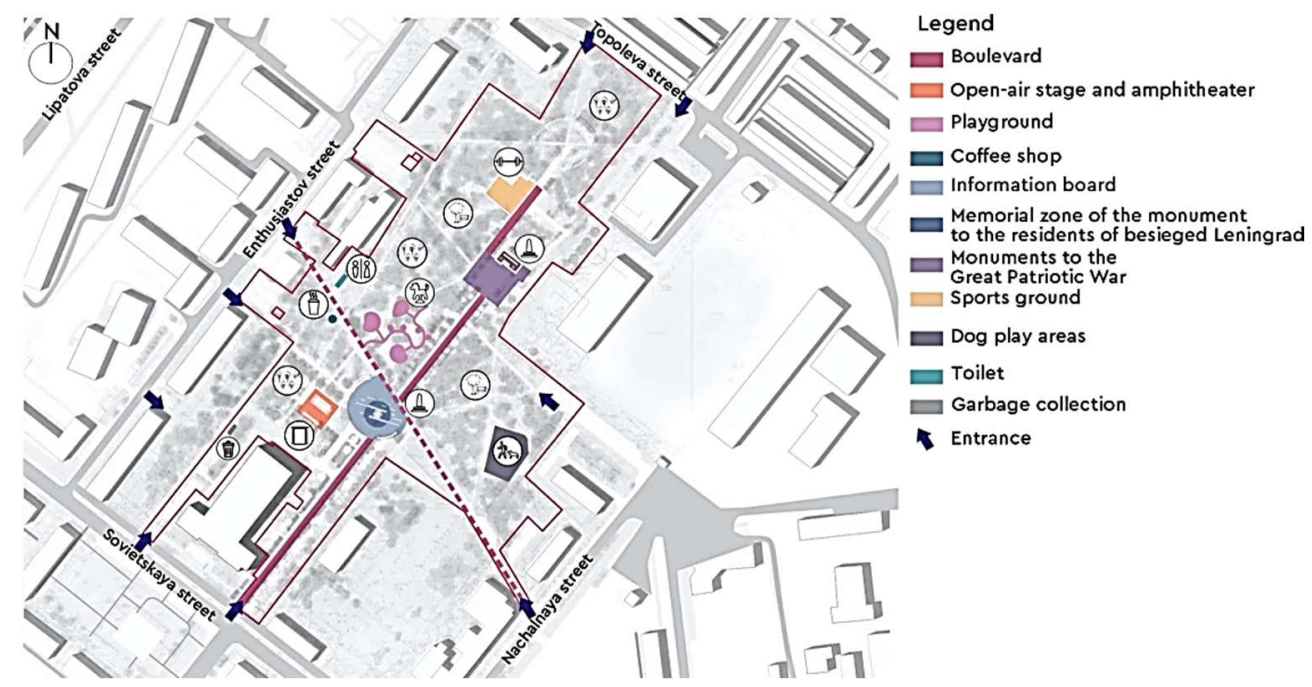

Fig. 2. Functional zoning scheme.

There is a name for each alley: Alley of Blockade Leningrad, Alley of Heroes, Klubnaya, Sportivnaya, Stadionnaya. This will be reflected in the concept of the park navigation. The project provides for the reconstruction of the lost stage and dance floor, the organization of a recreation 
area with a swing, strengthening the sports component with the creation of an interactive exposition reflecting the sports lifestyle of the residents of the settlement of Derbyshki.

The planning structure of the park preserves the existing landscape and the age-old pines that grow in the park. The forest area of the park is described, among other things, in the monograph «Landscape and architectural analysis of the park on the example of a park in Kazan» (Grishina M., 2013), in the thesis «Architectural and spatial development of city gardens and parks in Kazan in the Soviet period» (Grishina M., 2015). The natural part of the park provides for the location of a quiet recreation area, a children's play area, and a playground for sports. The importance of the main front alley of the park as the main compositional axis will be emphasized by dendrology - landscape and visual accents in the form of flowering bushes of lilac, jasmine and wild cherry.

One of the main themes in the concept is the theme of the Second World War. The project provides the restoration of the original appearance of the Monument to the Fallen Soldiers and the preservation of the dragons' teeth fortification symbol with the addition of an element of interactivity. Anti-tank dragons' teeth fortifications, defending the city from the German army, were built by the hands of St. Petersburg (former Leningrad) children and women. Therefore, the preservation and restoration of this symbol is very important for the residents of this district, first of all - for the surviving residents of the besieged Leningrad. The dragons' teeth fortification stands in the area of the monument to the inhabitants of the besieged Leningrad are transformed into interactive stands with the history of the settlement of Derbyshki, the history of heroes - on the one side, and with the silhouettes of Kazan and St. Petersburg (former Leningrad) - on the other (Fig. 3).
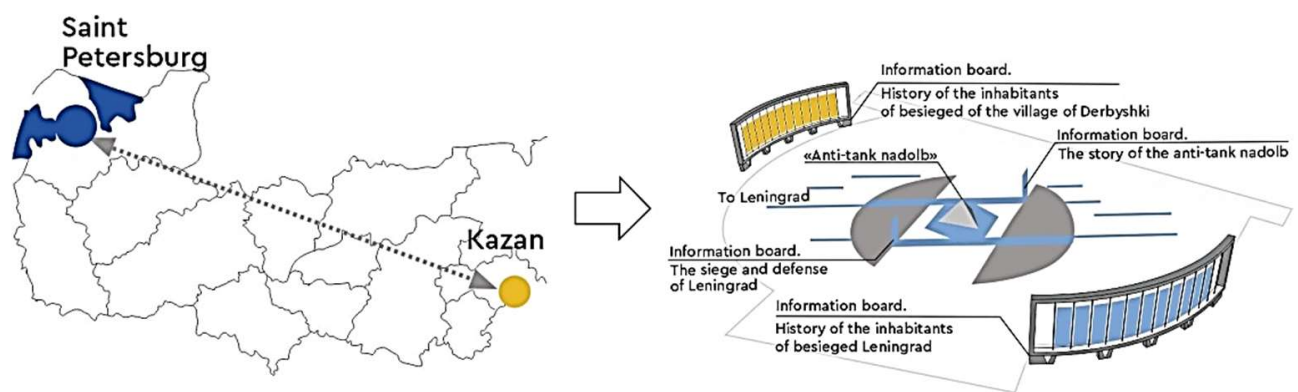

Fig. 3. The concept of interactive stands.

When holding events for the festivalization of space, it is possible to use the following types of temporary architectural structures and small architectural forms:

- seasonal pavilions;

- modular buildings;

- technical, public, cultural facilities: places for master classes, special tents, work areas for employees, etc.;

- art objects for the photo zone;

- art installations;

- polygonal figures of animals;

- small forms in the format of sites (for relaxation and yoga);

- ice and snow sculptures and structures.

Due to temporary architectural structures, small architectural forms and art objects, eventful architecture is created and the park is being transformed into new cultural spaces.

Thus, the recommendations proposed in the study for the reorganization of the park near the Community Centre named after Said-Galeevwhile preserving the local identity of the territory take into account the current trends in the reorganization of urban public spaces, 
include the identified methods of festivalizing public spaces using temporary architecture in terms of the concept of «local identity».

\section{Conclusions}

The analysis of the components of the concept of public spaces local identity, as well as the definition of approaches to its broadcast during the reorganization and reconstruction of urban areas, allowed us to determine the basic principles of reorganization of public space while preserving local identity: complexity, multi-focus and synergy.

- Creation of local identity by modern means of architecture and design.

- Participatory: identifying potential users and stakeholders, involving the local community, identifying their needs and wishes.

- Festivals and scenarios of filling the space.

- Functional diversity of the territory, taking into account the interests of all groups of the target audience.

The positive assessment by the local community of the results obtained from the implementation of the project of the park near the Community Centre named after SaidGaleev showed the effectiveness of the chosen method of work on projects for the reconstruction of public spaces, taking into account the preservation of local identity and its modern interpretation.

Identification of the components of the concept of local identity is impossible without the use of participatory (inclusive) design methods, involving the participation of all interested parties in the design process (local residents, administration, property owners, etc.). The participation of the local community at all stages of design - from concept development to implementation - allows not only identifying elements of the local identity of the public space, outlining the spectrum of socio-cultural diversity, and taking into account the cultural and historical context, but it also allows strengthening the level of emotional attachment to the territory among local residents and forming a personal connection of an individual with the city.

The festivalization (eventification) of the territory makes it possible to actualize the intangible cultural heritage of the city, creates the «sustainability» of the space, ensures its further development, and becomes the driver of the development of the adjacent urban areas. Public space and its use may vary depending on the time of the year (seasonal use), from cultural events held (event use), it may be associated with the location of temporary architectural objects in the public space.

\section{References}

1. Local identity as a new economy. Heritage, Project Russia. URL: https://prorus.ru/interviews/lokalnaya-identichnost-kak-novaya-ehkonomika-nasledie/ (reference date 03.25.2021).

2. S. Treija, U. Bratuškins, S. Barvika, E. Bondars. The liveability of historical cities: Current state and prospects for habitation, WIT Transactions on the Built Environment 193, 15-26 (2020).

3. K. Lynch Image of the city. URL: http://www.glazychev.ru/books/translations/Linch/ Linch_1.htm (reference date 03.25.2021).

4. N.S. Diaghileva. Theoretical aspects of urban identity, Branding of small and mediumsized cities in Russia: experience, problems, prospects 11, 54-59 (2013).

5. E. Erickson Identity: Youth and Crisis (1996).

6. M.V. Yakovleva. Features of the sociological analysis of urban symbolism as a factor in the formation of the identity of citizens, Bulletin of the Udmurt University 1, 83-90 (2008). 
7. Y. Yoshimura, S. He, G. Hack et al. Quantifying Memories: Mapping Urban Perception, Mobile NetwAppl 25, 1275-1286 (2020). DOI: 10.1007/s11036-020-01536-0.

8. S. Holl, J. Pallasmaa, A. Perez-Gomez. Questions of Perception, Phenomenology of Architecture, 155 (2006).

9. S.V. Melnikova. Analysis of the categories identity, image, image, brand in relation to the city, Improvement of humanitarian technologies in the educational space of the university: factors, problems, prospects : materials of the International Scientific and Methodological Seminar, Yekaterinburg, March 18, 2015, Yekaterinburg, 215-222 (2015).

10. S. Chatzitoulousis, V. Vlasidis, A. Sarris, K. Efkleidou, E. Kotjabopoulou, N. Papadopoulos, N. Argyriou, J. Donati, M. Manataki, P. Trapero-Fernandez. Records and Transformations of Memories in the Cultural Landscape of Idomeni (Kilkis, Northern Greece), Open Archaeology 5 (1), 563-585 (2019). DOI: 10.1515/opar-2019-0035.

11. R.M. Schafer. The Soundscape: Our Sonic Environment and the Tuning of the World. Rochester (VT): Destiny Books, 320 (1994).

12. K.S. Mayorova, Urban sound studies: New Horizons for Urban Studies, Urban Studies and Practices 4, 11-19 (2017).

13. A. Jaszczak, E. Pochodyła, K. Kristianova, N. Małkowska, J.K. Kazak. Redefinition of Park Design Criteria as a Result of Analysis of Well-Being and Soundscape: The Case Study of the Kortowo Park (Poland), Int. J. Environ. Res. Public Health 18, 2972 (2021). DOI: $10.3390 /$ ijerph18062972.

14. A. Shchenkov, N. Antonova. Architectural heritage and identity of Russian cities, Project Baikal 65, 27-31 (2021). DOI: 10.51461/PROJECTBAIKAL.65.1670.

15. A. Jaszczak, K. Kristianova, E. Pochodyła, J.K. Kazak, K. Młynarczyk. Revitalization of Public Spaces in Cittaslow Towns: Recent Urban Redevelopment in Central Europe, Sustainability 13, 2564 (2021). DOI: 10.3390/ su13052564.

16. G. Roy. Authenticity v/s glocalization as represented in the digital platforms: A study on the food culture with special reference to tripura, Rupkatha Journal on Interdisciplinary Studies in Humanities 12 (5), (2021). DOI: 10.21659/rupkatha.v12n5.rioc1s17n7.

17. D. Jakob. The eventification of place: Urban development and experience consumption in Berlin and New York City, European Urban and Regional Studies 20 (4), 447-459 (2013). DOI: 10.1177/0969776412459860.

18. R. Janiskee. South Carolina's harvest festival: Rural delights for day tripping urbanites, Journal of Cultural Geography 1, (1980).

19. S.D. Vita. The regional scale of contemporary mega-events The Milan Expo 2015, the post-event and the challenges for public policies and spatial planning, Mega-Events: Placemaking, Regeneration and City-Regional Development 5, 70-86 (2019). DOI: 10.4324/9780429466595-5.

20. M. Roche. Festivalization, cosmopolitanism and european culture: On the sociocultural significance of mega-events, Festivals and the Cultural Public Sphere, 124-141 (2011). DOI: $10.4324 / 9780203818787$.

21. S. Everett, D. John Parakoottathil. Transformation, meaning-making and identity creation through folklore tourism: the case of the Robin Hood Festival, Journal of Heritage Tourism 13 (1), 30-45 (2018). DOI: 10.1080/1743873X.2016.1251443.

22. A.G. Sabiescu. Living Archives and The Social Transmission of Memory Curator 63 (4), 497-510 (2020). DOI: 10.1111/cura.12384.

23. C. Suau. Reactivating urban voids through sensory and pop-up design: Changing citizen perceptions of remaking with waste, Handbook of Research on Perception-Driven Approaches to Urban Assessment and Design, 534-558 (2018). DOI: 10.4018/978-15225-3637-6.ch023. 
24. R. Luck. Inclusive design and making in practice: Bringing bodily experience into closer contact with making, Design Studies 54, 96-119 (2018). DOI: 10.1016/j.destud. 2017.11.003.

25. R. Luck. Participatory design in architectural practice: Changing practices in future making in uncertain times, Design Studies 59, 139-157 (2018). DOI: 10.1016/j.destud. 2018.10.003.

26. R. Luck. What is it that makes participation in design participatory design?, Design Studies 59, 1-8 (2018). DOI: 10.1016/j.destud.2018.10.002.

27. P.V. Kapustin, A.I. Gavrilov. Problems of Analysis of Design and Research Methods of Interaction with the Urban Environment, Scientific Journal of Construction and Architecture 3 (59), 99-110 (2020).

28. I. Mulder. Co-creative partnerships as catalysts for social change, Strategic Design Research Journal 11 (3), 178-185 (2018). DOI: 10.4013/sdrj.2018.113.01.

29. K. Careva, R. Lisac, T. Pletenac, J. Vukić. City acupuncture as a participatory tool in revitalizing public space, Prostor 25 (2), 190-199 (2017). DOI: 10.31522/p.25.2(54).2.

30. V. Kazakova. «Town of all trades» in Shilka: Creation of a comfortable environment, Project Baikal 65, 74-79 (2021). DOI: 10.51461/projectbaikal.65.1680.

31. CO-Create Charoenkrung. URL: https://archello.com/project/co-create-charoenkrung-2 (reference date 03.25.2021).

32. L.H. Lofland. The Public Realm. New York: Aldine De Gruyter, (1998).

33. A.L. Gelfond. Architecture of public spaces: monograph. M.: INFRA-M, 412 (2019).

34. L. Grundlingh. The great outdoor living room of the city: A survey essay on the thoughts and aims of urban park development in the late $19^{\text {th }}$ and early $20^{\text {th }}$ century in Europe and the United States of America, Tydskrif vir Geesteswetenskappe 57 (2), $542-561$ (2017). DOI: $10.17159 / 2224-7912 / 2017 / \mathrm{v} 57 \mathrm{n} 2-2 \mathrm{a} 4$.

35. Д. Джекобс. Death and Life of Large American Cities Moscow: New Publishing House, 460 (2011).

36. What is the city talking about? How to make dialogue the basis of urban development. Recordings of lectures World Urban Parks Congress. URL: https://youtu.be/ yJZyBoGTyYw/ (reference date 03.25.2021). 